\title{
How can a knowledge of the past help to conserve the future? Biodiversity conservation and the relevance of long-term ecological studies
}

\author{
Katherine J. Willis ${ }^{1, *}$, Miguel B. Araújo ${ }^{2}$, Keith D. Bennett ${ }^{3}$, \\ Blanca Figueroa-Rangel ${ }^{1}$, Cynthia A. Froyd ${ }^{1}$ and Norman Myers ${ }^{4}$ \\ ${ }^{1}$ Long-term Ecology Laboratory, and ${ }^{4}$ Visiting Professor at School of Geography, \\ Oxford University Centre for the Environment, South Parks Road, Oxford, OX1 3QY, UK \\ ${ }^{2}$ Department of Biodiversity and Evolutionary Biology, National Museum of Natural Sciences, \\ C/fosé Gutiérrez Abascal 2, Madrid 28006, Spain \\ ${ }^{3}$ Department of Earth Sciences, Palaeobiology, Villavägen 16, 75236 Uppsala, Sweden
}

\begin{abstract}
This paper evaluates how long-term records could and should be utilized in conservation policy and practice. Traditionally, there has been an extremely limited use of long-term ecological records (greater than 50 years) in biodiversity conservation. There are a number of reasons why such records tend to be discounted, including a perception of poor scale of resolution in both time and space, and the lack of accessibility of long temporal records to non-specialists. Probably more important, however, is the perception that even if suitable temporal records are available, their roles are purely descriptive, simply demonstrating what has occurred before in Earth's history, and are of little use in the actual practice of conservation. This paper asks why this is the case and whether there is a place for the temporal record in conservation management. Key conservation initiatives related to extinctions, identification of regions of greatest diversity/threat, climate change and biological invasions are addressed. Examples of how a temporal record can add information that is of direct practicable applicability to these issues are highlighted. These include (i) the identification of species at the end of their evolutionary lifespan and therefore most at risk from extinction, (ii) the setting of realistic goals and targets for conservation 'hotspots', and (iii) the identification of various management tools for the maintenance/restoration of a desired biological state. For climate change conservation strategies, the use of long-term ecological records in testing the predictive power of species envelope models is highlighted, along with the potential of fossil records to examine the impact of sea-level rise. It is also argued that a long-term perspective is essential for the management of biological invasions, not least in determining when an invasive is not an invasive. The paper concludes that often inclusion of a long-term ecological perspective can provide a more scientifically defensible basis for conservation decisions than the one based only on contemporary records. The pivotal issue of this paper is not whether long-term records are of interest to conservation biologists, but how they can actually be utilized in conservation practice and policy.
\end{abstract}

Keywords: conservation practice and policy; long-term ecology; extinctions; Red Data List; biodiversity hotspots; climate change

\section{INTRODUCTION}

Key conservation initiatives that are currently the focus of much attention include (i) identifying those species most at threat from extinction (e.g. 2004 International Union for Conservation of Nature and Natural Resources (IUCN) Red List of Threatened Species, http://www. iucnredlist.org), (ii) identifying regions with greatest diversity (species richness, endemism, genetic) and/or under greatest threat (e.g. Myers et al. 2000; Hoekstra et al. 2005; Orme et al. 2005), (iii) predicting distributional responses of plants/animals to future climate change (Pearson \& Dawson 2003), and (iv) documenting biological invasions (Peterson 2003; Henderson et al. 2006). The scope of these is extremely broad, ranging

* Author for correspondence (kathy.willis@ouce.ox.ac.uk).

One contribution of 14 to a Theme Issue 'Biodiversity hotspots through time: using the past to manage the future'. in scale from biomes through to genes, and is predominantly the realm of the conservation scientists (focusing primarily on existing or predicted future conditions). But the outputs from all of these initiatives are, in a sense, descriptive; they tend to provide the information on where and what to conserve but not on how to conserve. A second, parallel set of conservation initiatives therefore occurs whose key focus is the practice of conservation. These tend to be based around human dimensions, for example, working with local farmers/ groups in order to manage biodiverse landscapes in a sustainable manner (e.g. agroforestry) or to protect particular landscapes/species through the management of reserves (Borgerhoff Mulder \& Coppolillo 2005). The scope of these is also broad and ranges from those developed in conjunction with individuals through to organizations, project alliances, governments and 


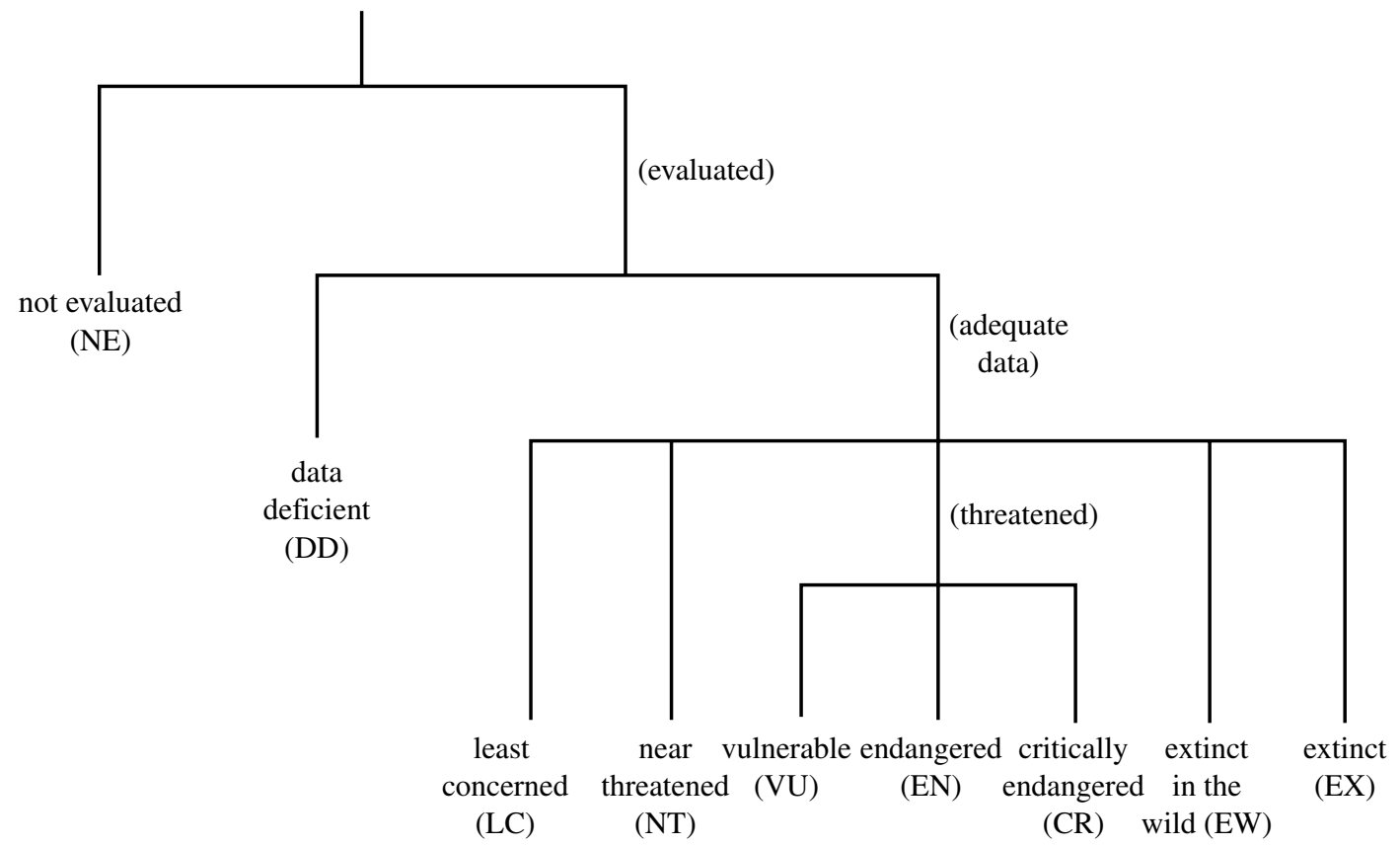

Figure 1. Terminology used in the classification of species for the IUCN Red Data List (redrawn from IUCN 2004).

networks (Salafsky et al. 2002). These initiatives tend to be the realm of the social scientists, including anthropologists, economists, politicians, land-use planners and sociologists.

There are close links between conservation initiatives that focus on biodiversity science and those that focus on policy and management, and in an ideal world they would be inextricably linked (Predergast et al. 1999). Such linkages are often fostered via both government and non-government conservation organizations (e.g. Worldwide Fund for Nature (WWF), Conservation International (CI), etc.). Thus, a briefest examination of web-based literature from some of these leading conservation organizations reveals not only information on conservation science, but also how this information is utilized in practice (e.g. http://www.conservation.org/xp/ CIWEB/). Yet, it is at this interface between science and policy that there is a total lack of acknowledgement of any temporal record greater than $c a 50$ years (Willis et al. 2005). Given that the average generation time of many of the higher order organisms of concern (e.g. trees, large mammals) is often between 20 and 100 years, these records barely cover one generation.

This paper asks why temporal records greater than 50 years are not being routinely used in conservation management, either in the science of measuring change or to inform policy and management. What more can be gained from these records, beyond that which is provided by the current and the recent historical record? Is there any need to know about what has occurred over longer time-scales when what we are facing in terms of biodiversity loss has, by all accounts, accelerated beyond all previous known rates and is a key concern of the future (Lawton \& May 1995; Pimm \& Lawton 1998)?

These questions will be addressed by examining four key conservation initiatives related to extinctions, regions of greatest diversity/threat, climate change and biological invasions, and by asking what additional information can be provided by long-term records? For each, the potential of long-term records will be discussed and examples where such techniques could be/have been successfully applied to conservation projects are highlighted.

In this paper, the long-term records addressed are predominantly those provided by the fossil record (e.g. fossil pollen, plant macrofossils, microfossil charcoal) and the molecular phylogenies. It should be noted, however, that there are a number of other long-term records covering the historical time-scale ( ca 50-1000 years ago) contained in old maps, aerial photographs, early traveller's diaries and archival records (reviewed in Egan \& Howell 2005).

\section{CONSERVATION INITIATIVES RELATED TO MEASURING EXTINCTIONS}

The loss of species through extinctions is deemed to be one of the most pressing issues for conservation practitioners and barely a week goes past without a headline in the international press concerning predicted extinction rates for one group or another. This information is based sometimes on independent ecological studies (e.g. Thomas et al. 2004), but probably more often on data collected and collated in the IUCN Red Data List. The IUCN Red List system was first conceived in 1963 to provide a comprehensive inventory of the global conservation status of plant and animal species (IUCN 2000). It uses a set of criteria to evaluate the extinction risk of thousands of species and subspecies, and inventories have been made in a number of years since this with searchable results on the web and published in IUCN volumes (e.g. IUCN Red List of Threatened Species (2004), http://www. iucnredlist.org). The inventories are undertaken by conservation practitioners local to the region and species within them classified according to a set of pre-defined criteria. There are now nine categories, including the classifications critically endangered, endangered and vulnerable to extinction (figure 1). New species are being added all the time to the Red Data List and for some groups that were first measured 
in 1963 there now exists a record on rates of extinction spanning more than four decades. The Red Data List is a huge undertaking and the data it provides are invaluable for making a quantitative assessment of extinction rates and identifying those species most under threat; information that is fed directly into conservation policy and management. So what more can the fossil record add?

Whenever extinction rates are discussed in conservation literature, there is invariably a mention of the mass extinctions that have occurred at least five times previously in Earth's history and recorded in the geological record (for a review, see Willis \& McElwain 2002). Some useful information has been obtained from these studies of the fossil record, not least that the current rate of loss of species is comparable, if not faster, to those seen in previous extinction events (Futuyma 1998). There is also the calculation that while following previous mass extinctions there have been large diversification events, these may take up to $10 \mathrm{Myr}$ to occur and only happen once the cause of the extinction event has been removed (Myers \& Knoll 2001). But there are also serious problems with using the fossil record to understand these events, not least because the further back in time one goes, the more crude the temporal and spatial resolutions are. There are notable exceptions (see for instance Benton \& Twitchett (2003) on the end-Permian mass extinction), but even if a detailed temporal record across a previous mass extinction event is obtained, of what relevance is this to current conservation practice? Many would argue that it merely provides a description of patterns that have occurred before in Earth's history but has no direct applicability for management of the biodiversity loss currently underway. While this is a valid point in many respects, it has become embedded in conservation thinking and is often applied (wrongly) to all temporal studies on extinctions. There are, however, additional areas of research where a temporal record can provide much to the study of extinctions and deliver results that are of direct relevance to conservation policy and management.

A key objective of conservation initiatives associated with current extinctions is to detect small and declining populations. It is assumed that these are under the greatest threat of imminent extinction and should therefore be the main focus of initiatives to conserve and protect. In the classification for the Red Data List (2004 IUCN Red List of Threatened Species, http:// www.iucnredlist.org), for example, a 'critical' label is attached to small populations. Much effort is also put into determining the cause of their decline, because it is reasonably assumed that if this can be removed, the population will recover. However, for many species, the underlying assumption that small populations are in very great danger may in fact be flawed (Simberloff 1998). There are numerous examples in both fossil and extant records that some small, spatially restricted populations have persisted for thousands of years, and some species currently in decline are those typified by naturally fluctuating population size. Thus, one would expect such populations to exhibit declines even in the absence of new or increased threat and in a way the focus on the exact causes of extinction in very small populations often misses the conservation point... what biologists want to know is the process of decline in range and numbers' (Simberloff 1998).

Providing information on variability in population size and range through time is one area where data from the fossil record could provide information that is of direct applicability to conservation biologists. Not only previous spatial ranges of particular populations could be assessed, but also natural fluctuations in population size prior to the onset of anthropogenic activity (e.g. Behling \& Pillar 2007). In this way, the data from the fossil record could be used to determine the thresholds of natural variability and highlight those populations where the decline is real and thus should be a high priority for conservation.

A more controversial use of the fossil record in extinction-related conservation strategies, however, is to use it to identify which groups are at the end of their evolutionary life (e.g. Webb \& Gaston 2000). All groups have a finite period of life on Earth (Raup 1986) and more than $99 \%$ of all species that ever lived are now extinct (Jablonski 2004). Most of the extinctions in the past have occurred not within the mass extinction events but as a part of a naturally occurring on-going background extinction rate. It could therefore be argued that if a group is in the process of contraction, then it ought to be given a lower conservation priority than a group that is expanding. Otherwise, it would be like 'saving living fossils, something of human interest, but perhaps not beneficial to the protection of evolutionary processes and environmental systems that will generate future biodiversity' (Erwin 1991). Stanley (1979), using results of fossil studies, identified Muridae (mice and related animals), colubrid snakes and possibly frogs as examples of extant groups that are currently radiating especially rapidly. Twenty-five years further on, we now have a vastly expanded fossil record, including groups that were previously thought to be difficult to study in the fossil record (such as angiosperms and birds; figure 2). We also have a molecular phylogenetic record that has been developed entirely within the past decade. Information from these records indicate that modern birds are one group that have a relatively recent radiation evolving around the Cretaceous/Tertiary boundary ( $\mathrm{ca} 65 \mathrm{Myr}$ ) and the group is still increasing and diversifying (Clarke et al. 2005). However, there are a number of other groups (e.g. conifers, gingkoales and cycads) where all that are left are the remnants of a radiation that took place much earlier ( $c$ a $280 \mathrm{Myr}$ ) or have had no new originations, at least at familial level over the past $50 \mathrm{Myr}$ (e.g. gymnosperms; figure 2; Willis \& McElwain 2002). All fossil evidence suggests that these groups are naturally in decline.

There are currently 238 cycads on the Red Data List (with many of them classified as endangered or critically endangered), the one remaining gingko species (Gingko biloba) and a number of conifers (e.g. Wollemi pine). Therefore, given the knowledge from the fossil record, should resources continue to be focused on maintaining their persistence (e.g. The Cycad Action Plan, IUCN Report; Donaldson 2003) or are there other groups on which we should be expanding our focus in order to provide the necessary 

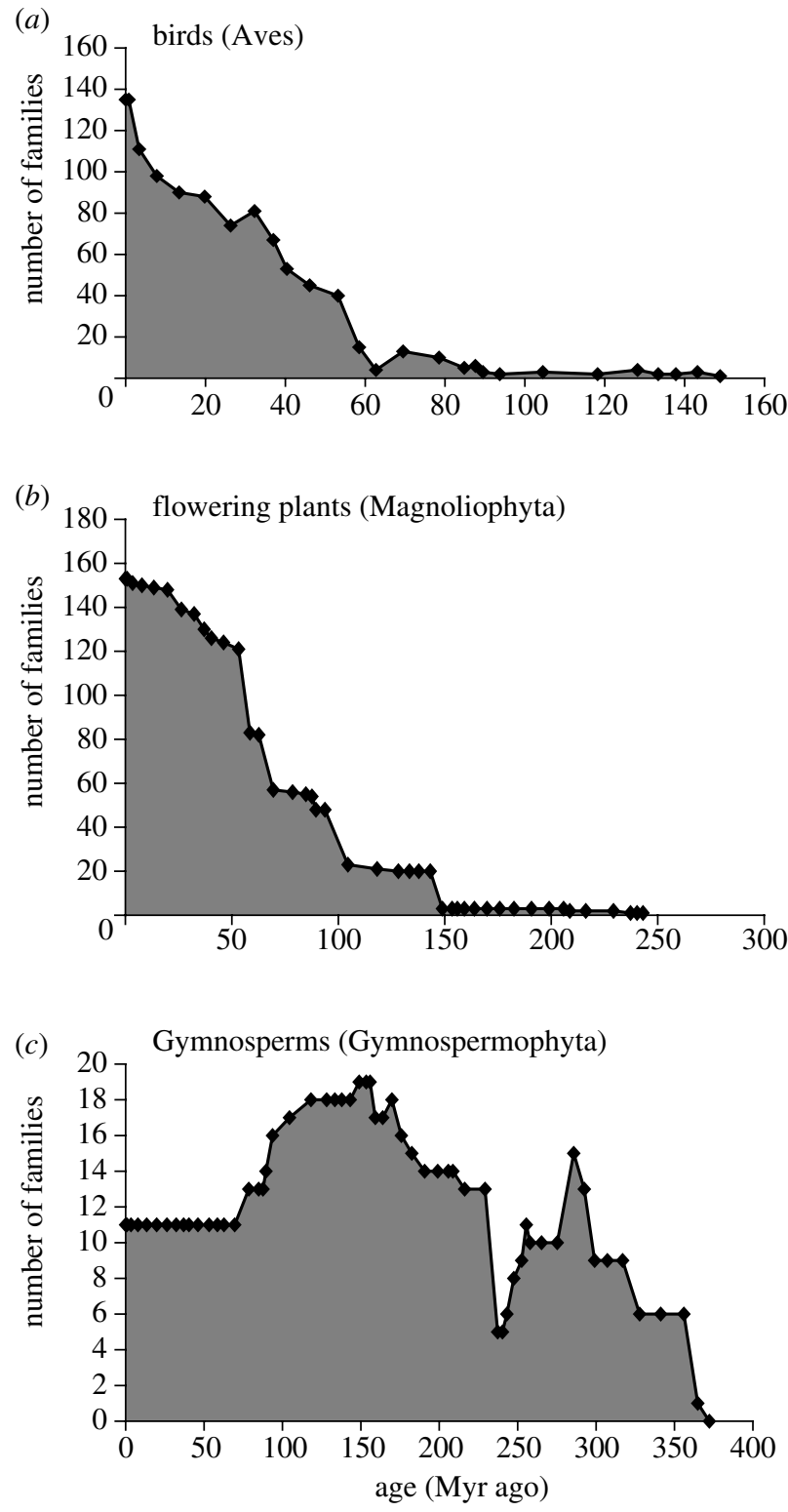

Figure 2. Fossil trends through time of birds (Aves), flowering plants (Magnoliophyta) and gymnosperms (Gymnospermophyta). Data from Cleal (1993: Gymnospermophyta), Collinson et al. (1993: Magnoliophyta) and Unwin (1993: Aves) and tabulated in Benton (1993).

conditions for speciation and natural expansion? The alternative viewpoint (and one that is probably more acceptable to the conservation community at large) is that species that are at the end of their evolutionary life should be given special conservation status (for example, with populations kept in botanical/zoological gardens). It could be argued that preservation of these 'rare' species is in some cases more important because if they are more likely to go extinct in the wild, important resources associated with them (e.g. medicinal, genetic) will be lost for ever (Donaldson 2003).

Whichever stance is taken, the fossil record has a large untapped potential in highlighting groups that are expanding and those that are in decline. Such information has direct applicability to conservation practice and suggests two very different lines of action depending on the status of the group in question. Those that are expanding might need preservation of conditions necessary for speciation. In comparison, those in decline might need a very different set of conservation measures, probably including the maintenance of populations in captivity or small intensively managed refugia.

\section{IDENTIFICATION AND MANAGEMENT OF REGIONS OF GREATEST DIVERSITY AND/OR UNDER GREATEST THREAT}

Another key research focus of conservation scientists is the identification of regions of greatest biodiversity in order to prioritize for conservation. A number of different measures have been used to determine where such regions occur (e.g. levels of richness, complementarity, endemism and rarity) and various labels devised to describe them. These include ecoregions (Olson et al. 2001), biogeographic crossroads (Spector 2002) and hotspots (e.g. Myers et al. 2000, Mittermeier et al. 2005; figure 3). In addition to measuring diversity, many of these methods also use in their calculation a measure of threat; in Myers et al. (2000), for example, in order to qualify as a hotspot, a region must have lost at least $70 \%$ of its original vegetation cover. This information is then used to prioritize and implement a huge array of conservation projects in these hotspots ranging from the small-scale initiatives working with individuals to the creation of large reserves in conjunction with government agencies.

In the identification of regions of greatest diversity, the fossil record probably has little more to add than that which is already known. Throughout Earth's history, there has always been a latitudinal cline in diversity and, similar to present, the low latitudes and in particular the tropical rainforests have harboured the greatest taxonomic diversity (Crame 2001; Willis \& McElwain 2002). It is in the implementation of conservation projects in these biodiverse regions, however, that the fossil record has huge amounts to offer.

In recent years, there has been much debate about what conservation prioritization schemes actually mean in practice. A principal pitfall recognized in many conservation projects is that of a failure to make conservation targets and goals explicit (Margules \& Pressey 2000; Redford et al. 2003). Ideally, it is argued, conservation goals should not only aim to maintain or attain a certain biological state, but also reduce current and future threats and develop practitioners that can use various tools 'to take effective action to detect and counter these threats' (Salafsky et al. 2002).

But what 'biological' state is to be maintained or attained? Do you go for the biological state pre-human activity and if so how far back do you go? Many hotspot regions have undergone significant human impact over hundreds if not thousands of years (Willis et al. 2004a). Consideration is also needed of climate conditions that are necessary for persistence or restoration of diversity in a region. For example, if the plan is to maintain or restore vegetation types that became established over the past 500 years, then it is highly probable that many would have germinated (originated) during the Little 


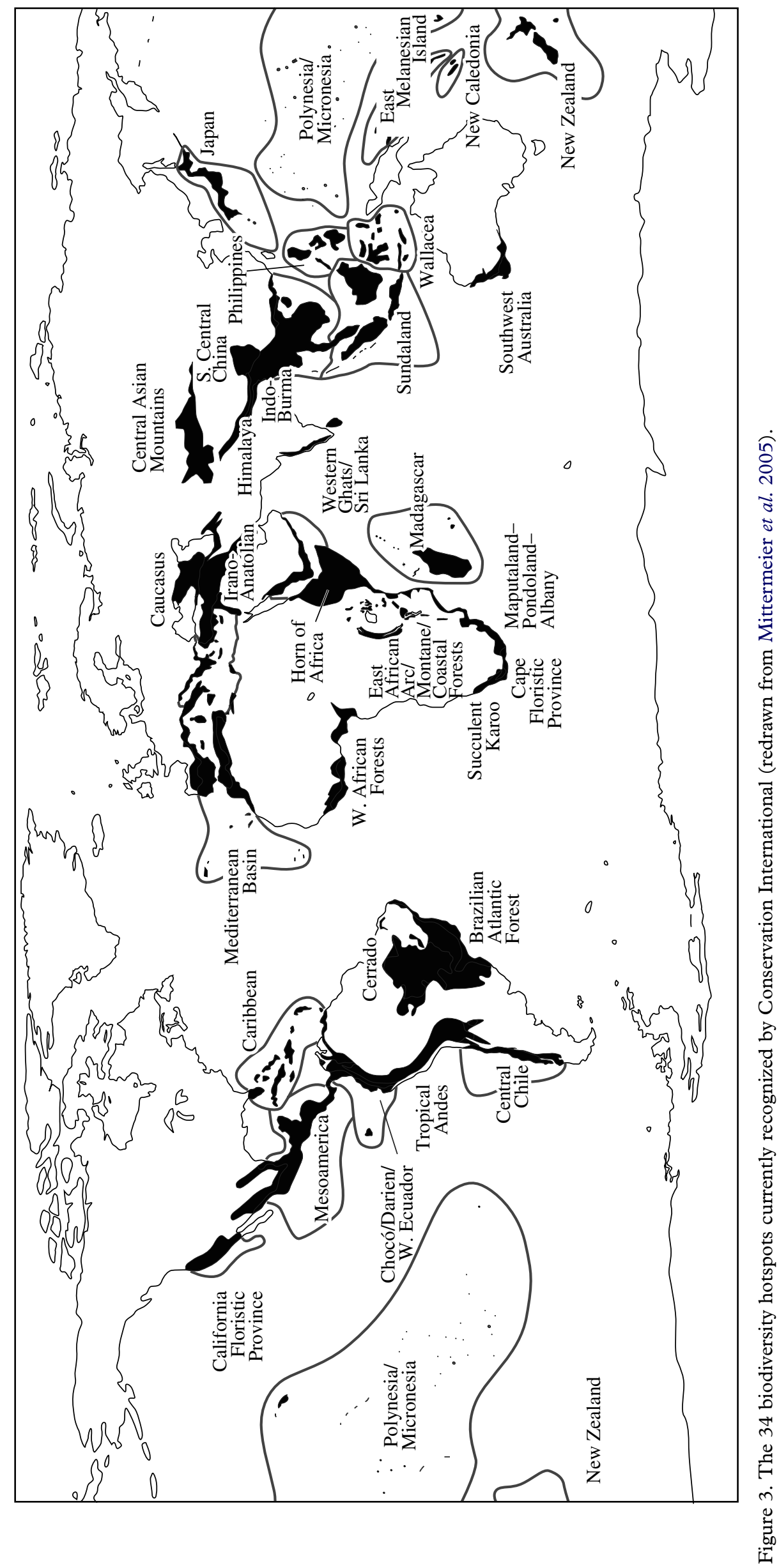


Ice Age (an event that resulted in global cooling between approximately $\mathrm{AD} 1350$ and $\mathrm{AD}$ 1870). Therefore, it might well be the case that climatic conditions are no longer ideal for the persistence or re-establishment of some of these species (Miller \& Woolfenden 1999; Gillson \& Willis 2004). Similarly, many so-called 'wilderness' landscapes have been affected by human interactions over millennia. If the goal is to maintain these wilderness landscapes, then there may well be particular management practices (e.g. burning, grazing) that are essential for long-term persistence of certain species/vegetation types. For example, recent studies have indicated that regeneration of African and Brazilian mahogany-rich forests requires disturbance; regeneration is inhibited by the presence of more shade-tolerant rainforest tree species (Brown et al. 2003) and it is likely that mahogany-rich forests originated following prehistoric disturbance, possibly burning (Snook 1996).

If realistic conservation goals are to be set for regions with greatest diversity and/or under greatest threat, then a temporal record of the region/species of concern can add much to this process. Not only can it suggest possible goals for conservation by providing a description of the 'biological state' of the species/region through time, but also information on the ecological processes and disturbance regimes responsible for this state, both of which can then be used in the development of effective management and restoration techniques (Chazdon 2003; Willis et al. 2004b).

There are some projects that are starting to use temporal records in 'goal/target' orientated conservation strategies. In the Galapagos Islands, for example, the Charles Darwin Foundation and the World Wildlife Fund (2002) have assembled a 'biodiversity vision analysis' for the region, asserting that the 'ultimate' goal in conservation of the Galapagos archipelago is 'the restoration of the populations and distributions of all extant native biodiversity and of natural ecological/evolutionary processes to the conditions prior to human settlement' (Snell et al. 2002). Assessment of biological diversity and ecosystem restoration of the Galapagos traditionally falls under the auspices of the scientific disciplines of ecology and conservation biology (Tye 2006). The analysis tools available in these disciplines, however, cannot on their own address the questions necessary to meet the restoration goals described above. In particular, the ecological restoration of native ecosystems to pre-human contact conditions requires an assessment of baseline ecological conditions on which to base conservation objectives. A multidisciplinary research project is therefore currently underway using a combination of long-term palaeoecological techniques and archaeological data to provide data that are of direct relevance and use to conservation practitioners (http://www.ouce.ox.ac.uk/research/biodiversity/lel/). Such studies, where palaeoecologists are working directly with conservation practitioners, addressing time-scales and research questions that are directly applicable to conservation, however, are few and far between and have tended to focus on Northern Hemisphere regions (e.g. Hallet \& Walker 2000; Motzkin \& Foster 2002: see, however, Gillson \& Duffin 2007).

\section{CLIMATE CHANGE CONSERVATION STRATEGIES}

Climate change and its impact on biodiversity conservation has been a topic of increasing interest and research over the past 10 years (Gascon et al. 2000, Sala et al. 2000; Hannah et al. 2002a). A number of the larger conservation organizations (e.g. CI, WWF) now have climate change-integrated conservation strategies (sensu Hannah et al. 2002a,b) and a suite of bioclimate models are being utilized in conservation. These include models to determine potential range shifts in species and biomes (e.g. Woodward \& Beerling 1997; Midgley et al. 2002; Berry et al. 2003; Thuiller et al. 2005; Araújo et al. 2006), as well as changes to terrestrial ecosystem structure and function (Cramer et al. 2000). Conservation strategies associated with the output from these models include ensuring that reserve boundaries allow for potential species range shifts (Araújo et al. 2004) and designing dispersal corridors among reserves (Williams et al. 2005). They also suggest conservation goals that incorporate an appreciation of changing abundances of populations and geographical variation associated with future climate change (Hannah et al. 2002b).

The potential for using a temporal record in conservation strategies is probably better realized for climate change than for all others. There are a number of key papers that have highlighted the importance of palaeoecological records in demonstrating past changes in abundances, distribution and the individualistic responses of species to climate change (e.g. Huntley \& Birks 1983, Huntley et al. 1995; Birks 1996; Davis \& Shaw 2001; Hannah et al. 2002b). Several important factors have emerged from these papers that directly challenge prevailing conservation beliefs. Palaeoecological studies have shown, for example, 'strong evidence that species move individualistically suggesting that communities are not discreet entities in most cases, making community 'representation' an impractical target overall' (Hannah et al. 2002b). There are also important region-specific studies, such as a palaeoecological study of the Andean flank (Bush 2002), where it has been demonstrated that if the location of the cloud forest during the Mid-Holocene warm event is used as a guide for future warming, it could move up the Andean flank by $600 \mathrm{~m}$ in the next century; an area of reduced size and an altitudinal band heavily dominated by anthropogenic activity (grazing).

There are two important areas of climate change conservation strategies, however, where the full potential of using a temporal record has yet to be realized. These are in those related to species-climate impact modelling and predicting the impacts of sea-level change.

\section{(a) Species-climate impact modelling}

There are currently a number of different speciesclimate impact models which combine the present-day distribution of plants and animals with current climate variables in order to project their distributions under future climatic scenarios (for a review, see Pearson \& Dawson 2003). However, these models are highly sensitive to the assumptions, algorithms and 
parameterizations of different methods (Araújo et al. $2005 b$ ), and the errors associated with them can result in misleading interpretations for conservation that are politically sensitive (Ladle et al. 2004). Understanding the percentage of error in the predictions when using different species-climate models in the development of conservation strategies must therefore be seen as essential, since it is only through knowing such information that uncertainty can be incorporated into strategic planning (Araújo et al. 2006; Pearson et al. 2006); this is an area where fossil studies have much to offer climate change conservation strategies.

A 'good' species-climate model is judged to be one in which outputs will match input data as closely as possible. However, very few studies carry out evaluation of models using direct comparison of model predictions with independent empirical observations (but see Araújo et al. 2005a). This is because climate change studies predict events that have not yet occurred. However, the temporal record has large amounts to offer in this respect through the testing of these models using backward prediction (hind casting). This is where the models are run for previous intervals of time using the present-day species dataset, but instead of current climate, a palaeoclimatic dataset is used to predict the past distribution of the species of interest. The predictions are then tested against the distribution of the species apparent in the fossil record for the interval in time covered by the palaeoclimatic data in order to detect the model fit.

To date, this method has only been carried out in a few studies and has been used more to test whether species climatic requirements (ecological niches) remain stable through time (Peterson et al. 1999; Martínez-Meyer et al. 2004), rather than testing the errors in various species envelope models. MartínezMeyer et al. (2004), for example, studied 23 extant mammal species in the USA and using a palaeoclimatic dataset for the time-interval Last Full Glacial (14 500-20 500 years before the present) predicted their distribution using a species envelope model (GARP). The output from this model was then compared to actual distribution data obtained from the fossil database FAUNMAP (FAUnMAP Working group 1994). The model was also run in reverse (i.e. using fossil data and palaeoclimatic data to predict present distribution) and similar comparisons made.

Results from this study indicated that for nine species, the model was able to accurately predict both Pleistocene distributions from the present-day data and vice versa. The remaining species either had significant predictions only one way but not the other (nine species) or were not significant in either direction (five species). Using the fossil record, therefore, it was possible to identify those species whose distribution could be predicted effectively and those that could not. Such studies must be seen as essential in order to properly use the species envelope modelling for conservation planning. Palaeoecological information could add much to the development and testing of these models for predicting future species' response to climatic change (Araújo et al. 2005a).

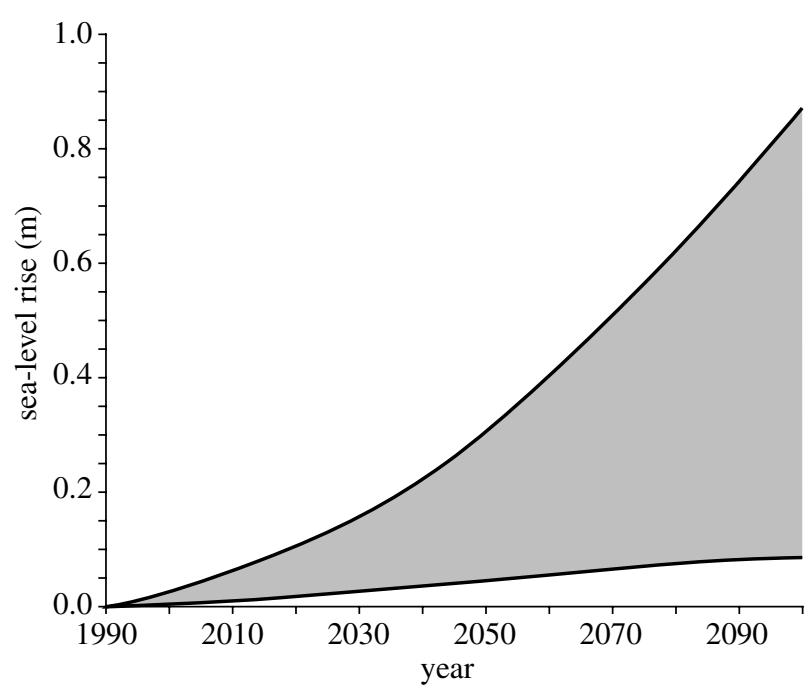

Figure 4. Predicted global average sea-level rise from 1990 to 2100 using various climate models (IPCC 2001). The region delimited by the outermost lines shows the range of all the predicted models and scenarios including uncertainty in land-ice changes, permafrost changes and sediment deposition. Note that this prediction does not allow for uncertainty and predictions related to the melting of the West Antarctic ice sheet (Alley et al. 2005).

\section{(b) Sea-level change}

Another climate change conservation strategy where a temporal record could have much to offer is in predicting the impacts of sea-level change on coastal biodiversity. Even in contemporary conservation practice and policy, limited attention has been paid to sea-level change (although see http://www.rspb.org. $\mathrm{uk} /$ policy/climatechange/adaptation/index.asp); the assumption is usually made that sea-level will probably have little effect beyond mangrove vegetation and that impacts of other processes (e.g. clearance) in coastal regions are more pressing.

The International Panel on Climate Change (IPCC) predicts a rise in sea-level by $0.5 \pm 0.4 \mathrm{~m}$ in the next century (figure 4). There is also the prediction of a rise in sea-level by approximately $70 \mathrm{~m}$ if the Greenland and Antarctic ice sheets melt completely (Alley et al. 2005). With at least 18 of the biodiversity hotspots having significant coastal margins, and given these predictions, there is a high probability that more than just mangroves will become inundated in the next century. Many of the atolls in the Pacific Ocean and the island groups in the Indian Ocean including the Maldives rise not more than 2-3 $\mathrm{m}$ above sea-level (Nunn 2004), and these, along with the Caribbean Islands, and coasts of southern Mediterranean, West Africa, East Africa, South Asian and Southeast Asia are most at risk of storm surges and flooding (Nicholls et al. 1999; figure 5). Recent predictions indicate that by 2080 between 20 and $70 \%$ of the world's coastal wetlands could be lost (Nicholls \& Lowe 2004); a number of significant coastal biodiversity hotspots are therefore destined for flooding.

Evidence from the fossil record (including fossil shorelines) indicates that sea-level was significantly higher than at present a number of times in the past, most recently from the Middle to Late Holocene (5000-1500 years ago; Pirazzoli 1991). In the equatorial Pacific, for example, both model predictions and 


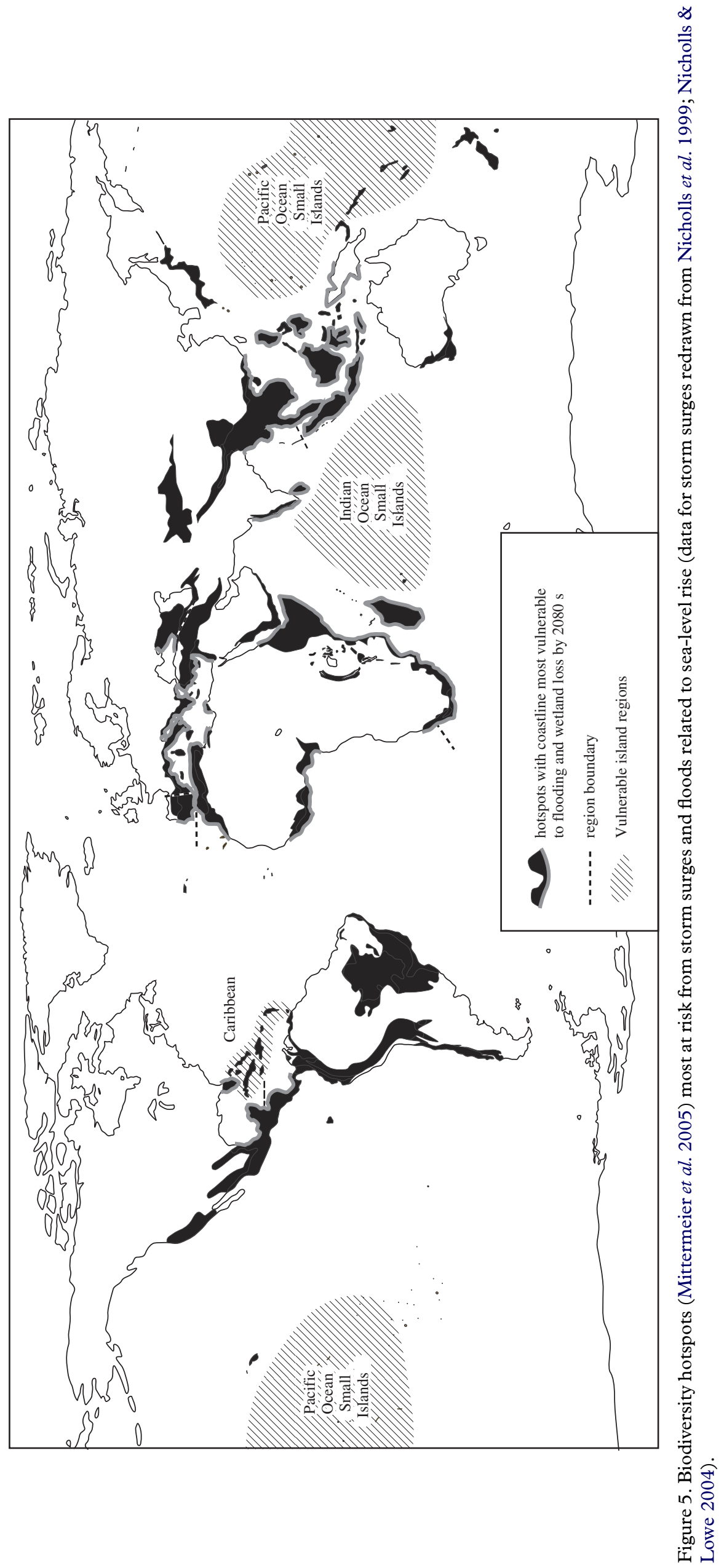


palaeoenvironmental reconstructions suggest that sea level was between 1 and $3 \mathrm{~m}$ higher than present between 5000 and 1500 years ago (Grossman \& Fletcher 1998; Grossman et al. 1998). Not only is this information significant for the interpretation and understanding of the evolution of reefs, atolls and prehistoric settlement patterns (Grossman et al. 1998), but also for understanding the past responses of coastal vegetation to marine inundation. Similar to the previously described examples using past species distributions to predict future movements in response to climate change (e.g. Bush 2002), temporal information on species responses to sea-level change should be invaluable. Given that sea-level rise is a prediction with reduced uncertainty (unlike a number of the other climate predictions; IPCC 2001), there is a strong argument for suggesting that species envelope modelling should be developed for assessing species movements in response to sea-level change. Fossil records from suitable coastal sedimentary environments (e.g. mangroves, littoral swamps) should be used to test these predictions through hind casting, providing information that is of direct relevance to climate change-integrated conservation strategies.

\section{CONSERVATION INITIATIVES RELATED TO BIOLOGICAL INVASIONS}

Conservation initiatives related to biological invasions are highly dependent upon information on the spatial extent of the invasive species, degree of impact on native species and ecosystems, and the rate and pattern of spread. The importance of the historical record in improving our ability to predict the outcome of non-native introductions has been acknowledged a number of times (e.g. National Research Council 2002) yet despite this, the application of long-term data to such analyses is rare. There are four key areas where there is much potential for the use of temporal records in conservation initiatives related to biological invasions as follows:

(i) One of the central ecological questions in invasive species research is determining what makes certain habitats more susceptible to invasion by non-indigenous species and, conversely, what enables certain species to become effective invaders (Didham et al. 2005). An understanding of the long-term record, particularly anthropogenic and natural disturbance histories, is fundamental to addressing such questions. Palynological, macrofossil and sedimentary charcoal records, for example, can provide evidence of the impacts of past burning, grazing and agricultural development; information that is critical in understanding potential triggers for the success of invasive species. Di Castri (1989) speculates that the invasion potential of species may be based on the long-term (pre-human impact) natural disturbance history of their region of origin, i.e. a species that originated within a region of frequent, severe disturbance would be more likely to thrive in an analogous situation of anthropogenically driven change. Additionally, 'good invaders' would also develop in areas with a long history of human cultural and agricultural development - the so-called 'synanthropic history hypothesis' (Di Castri 1989; Henderson et al. 2006).

(ii) A second area where the long-term ecological record has much to offer is in determining the natural range of a species. Within the pervading invasive species literature, the term 'native' is primarily used with reference to species in terms of their areas of evolutionary origin. But, as Calicott (2002) points out, there is often an unclear distinction between native and exotic species when examining longer time-scales, citing examples of species that are naturally extinct within their areas of evolutionary origin, but that exist for long periods of time outside of these regions (i.e. Camelidae and Equidae of North America). While these examples are extreme and no one (or at least very few people) is proposing that we actually attempt to re-create so-called 'Pleistocene parks' (but see Doland 2005), it does bring up some interesting questions of how we should define the natural range of species. The restoration literature often focuses on human agency as a criterion for this distinction (Noss \& Cooperrider 1994), but Callicott proposes that the use of the historic Holocene range (i.e. the current warm period under which modern ecosystems have developed) may be a more appropriate, less value-laden and more scientifically defensible basis for making the distinction between native and exotic species.

(iii) Another ecological dilemma in biological invasions that could gain much from an historical insight is the question of 'doubtful natives' (Jackson 1997). These are species for which it is currently unknown whether they are native or introductions to specific regions. As described previously, the goal for restoration activities within the Galapagos Islands is to restore 'all extant biodiversity...to the conditions prior to human settlement' (Charles Darwin Foundation and WWF). But, in the Galapagos, there are currently 60 species of vascular plants that have been provisionally classed as 'doubtful natives', organisms whose provenance is unknown (Mauchamp 1997; Snell et al. 2002; Tye 2006). Should the goal of restoration be the preservation or eradication of these species? Palaeoecological analysis can be used to resolve these questions by searching for the first occurrence of such species within the historic record and comparing it with timing of evidence of initial human activities. Species occurrence prior to human arrival in the Galapagos would indicate that it is a Holocene native.

(iv) Fourthly, a long temporal record can provide important data in predicting future impacts of invasive species as a result of climatic change (Jackson 1997). As already discussed, analysing past species' response to climatic changes can help to predict future species distributions-but how might this effect the impact of invasives? Benning et al. (2002) provide a good example of 
how information gained from palaeoecological investigation can be combined with known tolerances of invasive species to predict future, previously unforeseen impacts. Benning et al.'s work centres on endemic honeycreepers in the Hawaiian Islands, USA, a genus that has already experienced significant extinction since human occupation (Curnutt \& Pimm 2001). They used palaeoecological information to model future distributions of montane rainforest habitat and predicted temperatures. A significant risk from malaria exists to non-resistant native bird species. Malaria in the region is carried by the introduced mosquito (Culex quinquefasciatus) but development of the disease-causing parasite is temperature-dependent (Patz \& Reisen 2001). Benning et al.'s analysis indicates that there will be a significant future increase in the proportion of available honeycreeper habitat falling within the high-risk malaria zone; of particular concern is the island of Kauai where all montane forest will fall within a potential malarial area. This example clearly demonstrates the complex interaction of biological invasions with other factors under projected future climates. We cannot begin to address or even predict such occurrences without a strong emphasis on the analysis of past ecosystem response to climatic change that long temporal datasets can provide.

\section{CONCLUSIONS}

A review of potential uses of long-term ecological records in biodiversity conservation suggests that such records could greatly enhance many aspects of conservation practice and policy. It is argued that there are a number of specific areas where they should be routinely used in order to make conservation decisions that are less valueladen and instead founded on a more scientifically defensible basis (Calicott 2002).

Specific applications of long-term ecological records highlighted in this paper included those related to: (i) extinction related conservation initiatives and in particular methods to prioritize those species currently on the IUCN Red Data List based on past knowledge of species range, population and clade size, (ii) climate change conservation strategies and the use of the fossil record to determine the errors inherent in species envelope models and the responses of communities to sea-level rise, (iii) determination of baseline conditions for the maintenance and restoration of biodiversity hotspots, and (iv) biological invasions and using the fossil record to determine the environmental conditions that make certain habitats more susceptible to invasion, when an invasive is an invasive, rates of spread and the future impacts of invasive species as a result of climatic change.

The over-riding theme that has come through from the examination of these long-term ecological studies is that without an understanding of past variability, it may be impossible to manage for the present or future. Longterm records are particularly important for adding a conceptual and qualitative platform in which to view current and future conservation strategies and initiatives. But this is a conclusion that has been drawn many times before and still such studies are ignored by the conservation community at large. One possible reason for this is that there is far too little dialogue between conservation practitioners and palaeoecologists. Thus, the latter group continue to provide data that are interesting, descriptive, but of little applied use to specific conservation targets and goals, and the former group believe that all long-term ecological data are far too crude in spatial and temporal scale to be of any relevance. It is time to talk.

The authors wish to thank Anneli Ekbolm, Lindsey Gillson and Tim Hoffman for their helpful comments and discussions related to this paper. The Galapagos work mentioned in this paper is supported by a grant from the Natural Environmental Research Council (NE/C510667/1) awarded to K.J.W. and C.A.F.

\section{REFERENCES}

Alley, R. B., Clark, P. U., Huybrechts, P. \& Joughin, I. 2005 Ice-sheet and sea-level change. Science 310, 456-460. (doi:10.1126/science.1114613)

Araújo, M. B., Cabeza, M., Thuiller, W., Hannah, L. \& Williams, P. H. 2004 Would climate change drive species out of reserves? An assessment of existing reserve-selection methods. Global Change Biol. 10, 1618-1626. (doi:10.1111/ j.1365-2486.2004.00828.x)

Araújo, M. B., Pearson, R. G., Thuiller, W. \& Erhard, M. $2005 a$ Validation of species-climate impact models under climate change. Global Change Biol. 11, 1504-1513. (doi:10.1111/j.1365-2486.2005.01000.x)

Araújo, M. B., Whittaker, R. J., Ladle, R. \& Erhard, M. $2005 b$ Reducing uncertainty in projections of extinction risk from climate change. Global Ecol. Biogeogr. 14, 529-538. (doi:10. 1111/j.1466-822X.2005.00182.x)

Araújo, M. B., Thuiller, W. \& Pearson, R. G. 2006 Climate warming and the decline of amphibians and reptiles in Europe. F. Biogeogr. 33, 1365-2699.

Behling, H. \& Pillar, V. D. P. 2007 Late Quaternary vegetation, biodiversity and fire dynamics on the southern Brazilian highland and their implication for conservation and management of modern Araucaria forest and grassland ecosystems. Phil. Trans. R. Soc. B 362, 243-251. (doi:10. 1098/rstb.2006.1984)

Benning, T. L., LaPointe, D., Atkinson, C. T. \& Vitousek, P. M. 2002 Interactions of climate change with biological invasions and land use in the Hawaiian Islands: modelling the fate of endemic birds using a geographic information system. Proc. Natl Acad. Sci. USA 99, 14 246-14 249. (doi:10.1073/pnas.162372399)

Benton, M. J. (ed.) 1993 The fossil record 2. London, UK: Chapman and Hall.

Benton, M. J. \& Twitchett, R. J. 2003 How to kill (almost) all life: the end-Permian extinction event. Trends Ecol. Evol. 18, 358-365. (doi:10.1016/S0169-5347(03)00093-4)

Berry, P. M., Dawson, T. P., Harrison, P. A. \& Pearson, R. G. 2003 Modelling potential impacts of climate change on the bioclimatic envelope of species in Britain and Ireland. Global Ecol. Biogeogr. 11, 453-462. (doi:10.1111/j.14668238.2002.00304.x)

Birks, H. J. B. 1996 Contributions of quaternary palaeoecology to nature conservation. F. Veg. Sci. USA 7, 89-98. (doi: $10.2307 / 3236420$ )

Borgerhoff Mulder, M. \& Coppolillo, P. 2005 Conservation: linking ecology, economics, and culture. Princeton, NJ: Princeton University Press. 
Brown, N., Jennings, S. \& Clements, T. 2003 The ecology, silviculture and biogeography of mahogany (Swietenia macrophylla): a critical review of the evidence. Perspect. Plant Ecol. Evol. Syst. 6, 37-49. (doi:10.1078/1433-831900041)

Bush, M. B. 2002 Distributional change and conservation on the Andean flank: a palaeoecological perspective. Global Ecol. Biogeogr. 11, 463-473. (doi:10.1046/j.1466-822X. 2002.00305.x)

Calicott, J. B. 2002 Choosing appropriate temporal and spatial scales for ecological restoration. F. Biosci. 27, 409-420.

Chazdon, R. L. 2003 Tropical forest recovery: legacies of human impact and natural disturbances. Perspect. Plant Ecol. Evol. Syst. 6, 51-71. (doi:10.1078/1433-8319-00042)

Clarke, J. A., Tambussi, C. P., Noriega, J. I., Erickson, G. M. \& Ketcham, R. A. 2005 Definitive fossil evidence for the extant avian radiation in the Cretaceous. Nature 433, 305-308. (doi:10.1038/nature03150)

Cleal, C. J. 1993 Gymnospermophyta. In The fossil record 2 (ed M. J. Benton), pp. 795-808. London, UK: Chapman and Hall.

Collinson, M. E., Boulter, M. C., Holmes, P. L. \& Unwin, D. M. 1993 Manoliophyta ('Angiospermae'). In The fossil record 2 (ed M. J. Benton), pp. 809-841. London, UK: Chapman and Hall.

Crame, J. T. 2001 Taxonomic diversity gradients through time. Divers. Distrib. 7, 175-189.

Cramer, W. et al. 2000 Global response of terrestrial ecosystem structure and function to $\mathrm{CO}_{2}$ and climate change: results from six dynamic global vegetation models. Global Change Biol. 7, 357-373. (doi:10.1046/j.1365-2486.2001.00383.x)

Curnutt, J. \& Pimm, S. L. 2001 How many bird species in Hawaii and the central Pacific before first contact? Stud. Avian Biol. 22, 15-30.

Davis, M. B. \& Shaw, R. G. 2001 Range shifts and adaptive responses to quaternary climate change. Science 292, 673-679. (doi:10.1126/science.292.5517.673)

Di Castri, F. 1989 History of biological invasions with special emphasis on the Old World. In Biological invasions: a global perspective (eds J. A. Drake, J. A. Mooney, F. di Castrsi, R. H. Groves, F. J. Kruger, M. Rejmánek \& M. Williamson), pp. 1-26. Chichester, UK: Wiley.

Didham, R. K., Tylianakis, J. M., Hutchinson, M. A., Ewers, R. M. \& Gemmell, N. J. 2005 Are invasive species the drivers of ecological change? Trends Ecol. Evol. 20, 470-474. (doi:10.1016/j.tree.2005.07.006)

Doland, J. 2005 Re-wilding North America. Nature 436, 913-914. (doi:10.1038/436913a)

Donaldson, J. S. 2003. Cycads: status, survey and conservation action plan. Gland, Switzerland: International Union for Conservation of Nature and Natural Resources.

Egan, D. \& Howell, E. A. 2005 The historical ecology handbook. Washington, DC: Island Press.

Erwin, T. L. 1991 How many species are there? revisited. Conserv. Biol. 5, 330-333. (doi:10.1111/j.1523-1739.1991. tb00145.x)

FAUNMAP Working group 1994 Illinois State Mus. Sci. paper 25.

Futuyma, D. J. 1998 Evolutionary biology, 3rd edn. Sunderland, MA: Sinauer Associates.

Gascon, C., Williamson, G. B. \& da Foncesca, G. A. B. 2000 Receding forest edges and vanishing reserves. Science 288, 1356-1358. (doi:10.1126/science.288.5470.1356)

Gillson, L. \& Duffin, K. I. 2007 Thresholds of potential concern as benchmarks in the management of African savannas. Phil. Trans. R. Soc. B 362, 309-319. (doi:10. 1098/rstb.2006.1988)

Gillson, L. \& Willis, K. J. 2004 'As earth's testimonies tell': wilderness conservation in a changing world. Ecol. Lett. 7, 990-998. (doi:10.1111/j.1461-0248.2004.00658.x)
Grossman, E. E. \& Fletcher, C. H. 1998 Sea level higher than present 3500 years ago in the northern main Hawaiian Islands. Geology 26, 363-366. (doi:10.1130/00917613(1998)026<0363:SLHTPY> 2.3.CO;2)

Grossman, E. E., Fletcher, C. H. \& Richmond, B. M. 1998 The Holocene sea-level highstand in the equatorial Pacific: analysis of the insular paleosea-level database. Coral Reefs 17, 309-327. (doi:10.1007/s003380050132)

Hallet, D. J. \& Walker, R. C. 2000 Paleoecology and its application to fire and vegetation management in Kootenay National Park, British Columbia. f. Paleolimnol. 24, 401-414. (doi:10.1023/A:1008110804909)

Hannah, L., Midgley, G. F., Lovejoy, T., Bond, W. J., Bush, M., Lovett, J. C., Scott, D. \& Woodward, F. I. $2002 a$ Conservation of biodiversity in a changing climate. Conserv. Biol. 16, 264-268. (doi:10.1046/j.1523-1739. 2002.00465.x)

Hannah, L., Midgley, G. F. \& Millar, D. $2002 b$ Climate changeintegrated conservation strategies. Global Ecol. Biogeogr. 11, 485-495. (doi:10.1046/j.1466-822X.2002.00306.x)

Henderson, S., Dawson, T. P. \& Whittaker, R. J. 2006 Progress in invasive plants research. Prog. Phys. Geogr. 30, 1-22. (doi:10.1191/0309133306pp468ra)

Hoekstra, J. M., Boucher, T. M., Ricketts, T. H. \& Roberts, C. 2005 Confronting a biome crisis: global disparities of habitat loss and protection. Ecol. Lett. 8, 1-23. (doi:10. 1111/j.1461-0248.2004.00686.x)

Huntley, B. E. \& Birks, H. J. B. 1983 An atlas of past and present pollen maps for Europe 0-13,000 years ago. Cambridge, UK: Cambridge University Press.

Huntley, B., Berry, P. M., Cramer, W. \& McDonald, A. P. 1995 Modelling present and potential future ranges of some European higher plants using climate response surfaces. f. Biogeogr. 22, 967-1001. (doi:10.2307/2845830)

Intergovernmental Panel on Climate Change (IPCC) 2001 Climate change 2001:the scientific basis. Contribution of working group $I$ on the third assessment report of the intergovernmental panel on climate change. Port Chester, NY: Cambridge University Press.

IUCN 2004 Red list of threatened species. Gland, Switzerland: International Union for Conservation of Nature and Natural Resources.

Jablonski, D. 2004 Extinction: past and present. Nature 427, 589. (doi:10.1038/427589a)

Jackson, S. T. 1997 Documenting natural and human-caused plant invasions using paleoecological methods. In Assessment and management of plant invasions (eds J. O. Luken \& J. W. Thieret), pp. 37-55. New York: Springer Verlag.

Ladle, R. J., Jepson, P., Araújo, M. B. \& Whittaker, R. J. 2004 Dangers of crying wolf over risk of extinctions. Nature 428, 799. (doi:10.1038/428799b)

Lawton, J. H. \& May, R. M. 1995 Extinction rates. Oxford, UK: Oxford University Press.

Margules, C. R. \& Pressey, R. L. 2000 Systematic conservation planning. Nature 405, 243-253. (doi:10.1038/ 35012251)

Martínez-Meyer, E., Townsend Peterson, A. \& Hargrove, W. W. 2004 Ecological niches as stable distributional constraints on mammal speices, with implications for Pleistocene extinctions and climate change projections for biodiversity. Global Ecol. Biogeogr. 13, 305-314. (doi:10. 1111/j.1466-822X.2004.00107.x)

Mauchamp, A. 1997 Threats from alien species in the Galapagos Islands. Conserv. Biol. 11, 260-263. (doi:10. 1046/j.1523-1739.1997.95356.x)

Midgley, G. F., Hannah, L., Millar, D., Rutherford, M. C. \& Powrie, L. W. 2002 Assessing the vulnerability of species richness to anthropogenic climate change in a biodiversity hotspot. Global Ecol. Biogeogr. 11, 445-451. (doi:10.1046/ j.1466-822X.2002.00307.x) 
Millar, C. \& Woolfenden, W. B. 1999 The role of climate change in interpreting historical variability. Ecol. Appl. 9, 1207-1216.

Mittermeier, R. A., Gil, P. R., Hoffman, M., Pilgrim, J., Brooks, T., Mittermeier, C. G., Lamoureux, J. \& da Foncesca, G. A. B. 2005 Hotspots revisited: Earth's biologically richest and most endangered terrestrial ecoregions. Washington, DC: Conservation International.

Motzkin, G. \& Foster, D. R. 2002 Grasslands, heathlands and shrublands in coastal New England: historical interpretations and approaches to conservation. F. Biogeogr. 29, 1569-1590. (doi:10.1046/j.1365-2699.2002.00769.x)

Myers, N. \& Knoll, A. H. 2001 The biotic crisis and the future of evolution. Proc. Natl Acad. Sci. USA 98, 5389-5392. (doi:10.1073/pnas.091092498)

Myers, N., Mittermeier, R. A., Mittermeier, C. G., da Foncesca, G. A. B. \& Kent, J. 2000 Biodiversity hotspots for conservation priorities. Nature 403, 853-858. (doi:10. 1038/35002501)

National Research Council 2002 Committee on the Scientific Basis for Predicting the Invasive Potential of Nonindigenous Plants and Plant Pests in the United States. Predicting invasions of nonindigenous plants and plant pests. Washington, DC: National Academy Press.

Nicholls, R. J. \& Lowe, J. A. 2004 Benefit of mitigration of climate change for coastal areas. Global Environ. Change 14, 229-244. (doi:10.1016/j.gloenvcha.2004.04.005)

Nicholls, R. J., Hoozemans, F. M. J. \& Marchand, M. 1999 Increased flood risk and wetland losses due to global sealevel rise: regional and global analyses. Global Environ. Change 9, s69-s87. (doi:10.1016/S0959-3780(99)00019-9)

Noss, R. F. \& Cooperrider, A. Y. 1994 Saving nature's legacy: protecting and restoring biodiversity. Washington DC: Island Press.

Nunn, P. D. 2004 Through a mist on the ocean: human understanding of island environments. Tijdscr. Econ. Soc. Geogr. 95, 311-325. (doi:10.1111/j.1467-9663.2004. 00310.x)

Olson, D. M. et al. 2001 Terrestrial ecoregions of the world: a new map of life on earth. BioScience 51, 933-938. (doi:10. 1641/0006-3568(2001)051 [0933:TEOTWA]2.0.CO;2)

Orme, C. D. L. et al. 2005 Global hotspots of species richness are not congruent with endemism or threat. Nature 436, 1016-1019. (doi:10.1038/nature03850)

Patz, J. A. \& Reisen, W. K. 2001 Immunology, climate change and vector-borne diseases. Trends Immunol. 22, 171-172. (doi:10.1016/S1471-4906(01)01867-1)

Pearson, R. G. \& Dawson, T. E. 2003 Predicting the impact of climate change on the distribution of species: are bioclimatic envelope models useful? Global Ecol. Biogeogr. 12, 361-371. (doi:10.1046/j.1466-822X.2003.00042.x)

Pearson, R. G. et al. 2006 Model-based uncertainity in species' range prediction. F. Biogeogr. 33, 1365-2699.

Peterson, A. T. 2003 Projected climate change effects on Rocky Mountain and Great Plain birds: generalities of biodiversity consequences. Global Change Biol. 9, 647-655. (doi:10.1046/j.1365-2486.2003.00616.x)

Peterson, A. T., Soberón, J. \& Sánchez-Cordero, V. 1999 Conservatism of ecological niches in evolutionary time. Science 285, 1265-1267. (doi:10.1126/science.285.5431. 1265)

Pimm, S. L. \& Lawton, J. H. 1998 Planning for biodiversity. Science 279, 2068-2069. (doi:10.1126/science.279.5359. 2068)

Pirazzoli, P. A. 1991 World atlas of Holocene sea-level changes. New York, NY: Elsevier.

Prendergast, J. R., Quinn, R. M. \& Lawton, J. H. 1999 The gaps between theory and practice in selecting nature reserves. Conserv. Biol. 13, 484. (doi:10.1046/j.15231739.1999.97428.x)
Raup, D. M. 1986 Biological extinction in earth history. Science 231, 1528-1533. (doi:10.1126/science.11542058)

Redford, K. H. et al. 2003 Mapping the conservation landscape. Conserv. Biol. 17, 116-131. (doi:10.1046/ j.1523-1739.2003.01467.x)

Sala, O. E. et al. 2000 Global biodiversity scenarios for the year 2100. Science 287, 1770-1774. (doi:10.1126/science.287. 5459.1770)

Salafsky, N., Margoluis, R., Redford, K. H. \& Robinson, J. G. 2002 Improving the practice of conservation: a conceptual framework and research agenda for conservation science. Conserv. Biol. 16, 1469-1479. (doi:10.1046/j.1523-1739. 2002.01232.x)

Simberloff, D. 1998 Small and declining populations. In Conservation science and action (eds W. J. Sutherland), pp. 116-134. Oxford, UK: Blackwell Publishing.

Snell, H. L., Tye, A., Causton, C. E. \& Bensted-Smith, R. 2002 The status of and threats to biodiversity. A. biodiversity vision for the Galapagos Islands, pp. 30-47. Puerto Ayora, Ecuador: Charles Darwin Foundation and World Wildlife Fund.

Snook, L. K. 1996 Catastrophic disturbance, logging and the ecology of mahogany (Swietenia macrophylla King): grounds for listing a major tropical timber species in CITES. Is there a future for mahogany? Bot. F. Linn. Soc. 122, 35-46. (doi:10.1006/bojl.1996.0047)

Spector, S. 2002 Biogeographic crossroads as priority areas for biodiversity conservation. Conserv. Biol. 16, 1480-1487. (doi:10.1046/j.1523-1739.2002.00573.x)

Stanley, S. M. 1979 Macroevolution: pattern and process. San Francisco, CA: WH Freeman.

Thomas, C. D. et al. 2004 Extinction risk from climate change. Nature 427, 145-148. (doi:10.1038/nature02121)

Thuiller, W., Lavorel, S., Araújo, M. B., Sykes, M. T. \& Prentice, I. C. 2005 Climate change threats to plant diversity in Europe. Proc. Natl Acad. Sci. USA 102, 8245-8250. (doi:10.1073/pnas.0409902102)

Tye, A. 2006 Can we infer island introduction and naturalization rates from inventory data? Evidence from introduced plants in Galapagos. Biol. Invasions 8, 201-215. (doi:10.1007/s10530-004-3574-2)

Unwin, D. M. 1993 Aves. In The fossil record 2 (ed M. J. Benton), pp. 717-737. London, UK: Chapman and Hall.

Webb, T. J. \& Gaston, K. J. 2000 Geographic range size and evolutionary age in birds. Proc. R. Soc. B 267, 1843-1850. (doi:10.1098/rspb.2000.1219)

Williams, P., Hannah, L., Andelman, S., Midgley, G., Araújo, M. B., Hughes, G., Manne, L., Martinez-Meyer, E. \& Pearson, R. 2005 Planning for climate change: identifying minimum-dispersal corridors for the Cape Proteaceae. Conserv. Biol. 19, 1063-1074. (doi:10.1111/j.1523-1739. 2005.00080.x)

Willis, K. J. \& McElwain, J. C. 2002 The evolution of plants. Oxford, UK: Oxford University Press.

Willis, K. J., Gillson, L. \& Brncic, T. M. $2004 a$ How 'virgin' is virgin rainforest? Science 304, 402-403. (doi:10.1126/ science.1093991)

Willis, K. J., Gillson, L. \& Brncic, T. M. $2004 b$ Virgin rainforests and conservation. Science 305, 943b-9944. (doi:10.1126/science.305.5686.943b)

Willis, K. J., Gillson, L., Brncic, T. \& Figueroa-Rangel, B. 2005 Providing baselines for biodiversity measurement. Trends Ecol. Evol. 20, 107-108. (doi:10.1016/j.tree.2004. 12.003)

Woodward, F. I. \& Beerling, D. J. 1997 The dynamics of vegetation change: health warnings for equilibrium 'Dodo' models. Global Ecol. Biogeogr. Lett. 6, 413-418. (doi:10. 2307/2997350) 


\section{NOTICE OF CORRECTION}

The references Behling \& Pillar, and Gillson \& Duffin, are now presented in their correct form.

19 January 2007

The legend of figure 2 was incorrect in print, and should read as follows:

Figure 2. Fossil trends through time of birds (Aves), flowering plants (Magnoliophyta) and gymnosperms (Gymnospermophyta). Data from Cleal (1993: Gymnospermophyta), Collinson et al. (1993: Magnoliophyta) and Unwin (1993: Aves) and tabulated in Benton (1993).

Detailed errata will appear at the end of the volume.

7 February 2007 